\title{
Diapycnal dissolved organic matter supply into the upper Peruvian oxycline
}

\author{
Alexandra N. Loginova ${ }^{1}$, Sören Thomsen ${ }^{1,2}$, Marcus Dengler ${ }^{1}$, Jan Lüdke $^{1}$, and Anja Engel ${ }^{1}$ \\ ${ }^{1}$ GEOMAR Helmholtz-Centre for Ocean Research Kiel, Düsternbrooker Weg 20, Kiel 24105, Germany \\ ${ }^{2}$ LOCEAN-IPSL, IRD/CNRS/Sorbonnes Universites (UPMC)/MNHN, Paris, UMR 7159, France
}

Correspondence: Anja Engel (aengel@geomar.de)

Received: 12 June 2018 - Discussion started: 15 June 2018

Revised: 25 February 2019 - Accepted: 28 April 2019 - Published: 15 May 2019

\begin{abstract}
The eastern tropical South Pacific (ETSP) hosts the Peruvian upwelling system, which represents one of the most productive areas in the world ocean. High primary production followed by rapid heterotrophic utilization of organic matter supports the formation of one of the most intense oxygen minimum zones (OMZs) in the world ocean, where dissolved oxygen $\left(\mathrm{O}_{2}\right)$ concentrations reach less than $1 \mu \mathrm{mol} \mathrm{kg}{ }^{-1}$. The high productivity leads to an accumulation of dissolved organic matter (DOM) in the surface layers that may serve as a substrate for heterotrophic respiration. However, the importance of DOM utilization for $\mathrm{O}_{2}$ respiration in the Peruvian upwelling system in general and for shaping the upper oxycline in particular remains unclear so far. This study reports the first estimates of diapycnal fluxes and supply of $\mathrm{O}_{2}$, dissolved organic carbon (DOC), dissolved organic nitrogen, dissolved hydrolysable amino acids (DHAA) and dissolved combined carbohydrates (DCCHO) for the ETSP off Peru. Diapycnal flux and supply estimates were obtained by combining measured vertical diffusivities and solute concentration gradients. They were analysed together with the molecular composition of DCCHO and DHAA to infer the transport of labile DOM into the upper OMZ and the potential role of DOM utilization for the attenuation of the diapycnal $\mathrm{O}_{2}$ flux that ventilates the OMZ. The observed diapycnal $\mathrm{O}_{2}$ flux ( $50 \mathrm{mmol} \mathrm{O}_{2} \mathrm{~m}^{-2} \mathrm{~d}^{-1}$ at maximum) was limited to the upper $80 \mathrm{~m}$ of the water column; the $\mathrm{O}_{2}$ supply of $\sim 1 \mu \mathrm{mol} \mathrm{kg}{ }^{-1} \mathrm{~d}^{-1}$ was comparable to previously published $\mathrm{O}_{2}$ consumption rates for the North and South $\mathrm{Pa}-$ cific OMZs. The diapycnal DOM flux $\left(31 \mathrm{mmol} \mathrm{C} \mathrm{m}^{-2} \mathrm{~d}^{-1}\right.$ at maximum) was limited to $\sim 30 \mathrm{~m}$ water depth, suggesting that the labile DOM is extensively consumed within the upper part of the shallow oxycline off Peru. The analyses of
\end{abstract}

DCCHO and DHAA composition support this finding, suggesting that DOM undergoes comprehensive remineralization within the upper part of the oxycline, as the DOM within the core of the OMZ was found to be largely altered. Estimated by a simple equation for carbon combustion, aerobic respiration of DCCHO and DHAA, supplied by diapycnal mixing $\left(0.46 \mu \mathrm{mol} \mathrm{kg} \mathrm{k}^{-1} \mathrm{~d}^{-1}\right.$ at maximum $)$, could account for up to $38 \%$ of the diapycnal $\mathrm{O}_{2}$ supply in the upper oxycline, which suggests that DOM utilization plays a significant role for shaping the upper oxycline in the ETSP.

\section{Introduction}

Dissolved oxygen $\left(\mathrm{O}_{2}\right)$ plays a key role for biological production and cycling of elements in marine ecosystems as well as for the spatial distribution of marine organisms (Ekau et al., 2010; Gilly et al., 2013). The majority of catabolic processes in organisms are conducted by oxidation with $\mathrm{O}_{2}$ (e.g. Bender and Heggie, 1984). The eastern tropical South Pacific (ETSP) embodies one of the largest oxygen minimum zones (OMZs) in the world ocean (Karstensen et al., 2008; Paulmier and Ruiz-Pino, 2009). The core of the Peruvian OMZ is considered to be fully anoxic (e.g. Ulloa et al., 2012), as $\mathrm{O}_{2}$ concentrations below the detection limit (DL) of $\sim 0.01 \mu \mathrm{mol} \mathrm{kg} \mathrm{kg}^{-1}$ were observed between 20 and $400 \mathrm{~m}$ depth by high-precision STOX sensor measurements (Revsbech et al., 2009; Kalvelage et al., 2013; Thomsen et al., 2016a). Those low- $\mathrm{O}_{2}$ concentrations are due to a sluggish ventilation by ocean currents, carrying low- $\mathrm{O}_{2}$ waters to the ETSP, and microbial respiration attributed to utilization of organic matter $(\mathrm{OM})$ originating from the upper water column 
(e.g. Czeschel et al., 2011; Brandt et al., 2015; Kalvelage et al., 2015).

Elevated primary production in the Peruvian upwelling region above the OMZ (Pennington et al., 2006) leads to an accumulation of both particulate (POM) (Franz et al., 2012a) and dissolved (DOM) organic matter (Romankevich and Ljutsarev, 1990; Franz et al., 2012a; Letscher et al., 2013; Loginova et al., 2016) in the euphotic zone at the continental margin. POM was recognized to be an important source of carbon (C) for microbial OM mineralization (e.g. Dale et al., 2015), utilization of $\mathrm{O}_{2}$ (Kalvelage et al., 2015), and anaerobic processes, such as nitrogen $(\mathrm{N})$ loss via denitrification (Chang et al., 2010; Kalvelage et al., 2013), in the area. However, the cycling of DOM in the Peruvian upwelling system has been little studied.

DOM that originates in the euphotic zone, as a result of extracellular release by phytoplankton, cell lysis, particle degradation and sloppy zooplankton feeding (Benner, 2002), is commonly enriched in labile and semi-labile DOM. Those are mainly composed of carbohydrates (CHO) and amino acids (AA) (e.g. Ogawa and Tanoue, 2003). CHO and AA are preferentially utilized during microbial decomposition of OM as they serve as energy sources and "building blocks" for microbes to respire and grow (Skoog and Benner, 1997; Lee et al., 2000; Amon et al., 2001). Thus, the rapid microbial decomposition of labile organic matter in the euphotic zone is commonly followed by slower decomposition of less bioavailable semi-labile DOM and very slow decomposition of extensively reworked refractory DOM deeper in the water column (e.g. Hansell, 2013). Therefore, the composition of DOM reflects its diagenetic history, and the contribution of $\mathrm{CHO}$ and AA to DOM may be used as a measure of DOM bioavailability (Davis and Benner, 2007; Davis et al., 2009; Kaiser and Benner, 2009).

Microbial decomposition of organic matter has previously been suggested to be limited under anoxia (Harvey et al., 1995; Nguyen and Harvey, 1997). Following this suggestion, one may assume that, if labile DOM is mixed into the OMZ, it would not be reworked as rapidly as in oxygenated waters. Recent studies in the upwelling area and the corresponding OMZ off Chile found, however, that even under anoxia the ability of microbes to decompose labile DOM (leucineincorporation rate) did not differ from the oxygenated waters (Sempéré et al., 2008; Pantoja et al., 2009). These studies suggest that slower remineralization of DOM in OMZ might rather be caused by lack of bioavailable organic matter supply into the $\mathrm{OMZ}$ than by low- $\mathrm{O}_{2}$ conditions. Herewith, measured concentrations of bioavailable components of DOM over the water column in the ETSP are still controversial. For instance, Pantoja et al. (2009) reported relatively high concentrations of free and combined AA in the OMZ off Chile. Sempéré et al. (2008) reported low concentrations of neutral $\mathrm{CHO}$ in the corresponding upwelling area compared to the open Pacific Ocean.
In contrast to POM, DOM does not obtain its own buoyancy, and DOM's transport is exclusively due to advective and diffusive physical transport processes (e.g. Löscher et al., 2016). In upwelling regimes, turbulent mixing processes are often enhanced at the continental margin, resulting in high diapycnal fluxes of various solutes (e.g. Schafstall et al., 2010; Kock et al., 2012; Brandt et al., 2015; Steinfeldt et al., 2015). On the other hand, the downward fluxes of DOM, or other solutes, may be reduced or even predominated by upwelling fluxes due to Ekman divergence in the coastal upwelling region (e.g. Steinfeldt et al., 2015). Mahadevan (2014) suggested that transport of OM (via eddy fluxes) into the OMZ should be accompanied by $\mathrm{O}_{2}$ in an amount that is sufficient for full remineralization of the subducted OM. Therefore, this physical transport of $\mathrm{OM}$ and $\mathrm{O}_{2}$ should stimulate heterotrophic aerobic respiration in the OMZ that was suggested to be the main pathway of OM remineralization in the upper OMZs by Kalvelage et al. (2015). However, so far, no direct $\mathrm{O}_{2}$ and DOM supply estimates exist for the Peruvian OMZ.

Here, we combined physical and biogeochemical observational data that were collected during the R/V METEOR "M93" (M93) research cruise to the ETSP off Peru in February-March 2013. Specifically, we directly estimated the diapycnal $\mathrm{O}_{2}$ and DOM supply into the upper oxycline off Peru. Additionally, we analysed diapycnal fluxes and the composition of dissolved combined carbohydrates (DCCHO) and dissolved hydrolysable amino acids (DHAA) to learn whether DOM and its labile and semi-labile constituents may be supplied to the upper OMZ and the potential contribution of DOM-based respiration to $\mathrm{O}_{2}$ flux attenuation.

\section{Methods}

\subsection{Study area}

The observational data were acquired during research cruise "M93" that took place from 7 February to 9 March 2013 between 12 and $14^{\circ} \mathrm{S}$ and 76 and $79^{\circ} \mathrm{W}$ off Peru (Fig. 1). During the measurement programme, the study area was affected by moderate south-easterly winds $\left(1-9 \mathrm{~m} \mathrm{~s}^{-1}\right.$ ) (Thomsen et al., 2016a). The water column was highly stratified during the cruise (Fig. 2a, b). High concentrations of inorganic nutrients $\left(\sim 30 \mu \mathrm{mol} \mathrm{L}-1 \mathrm{NO}_{3}^{-}, \sim 3 \mu \mathrm{mol} \mathrm{L}{ }^{-1} \mathrm{PO}_{4}^{3-}\right)$ just below the surface (Thomsen et al., 2016a) collocated with the highest chlorophyll $a$ (chl $a$ ) concentrations near the surface (5-80 m depth; Fig. 2c) (Loginova et al., 2016). The oxycline was located at upper 5-80 m depth, where oxygen concentrations dropped from $>200$ to $<1 \mu \mathrm{mol} \mathrm{kg}{ }^{-1}$ (Fig. 2d) (Thomsen et al., 2016a). In summary, our observations were carried out during a period that corresponds to typical austral summer conditions off Peru. 


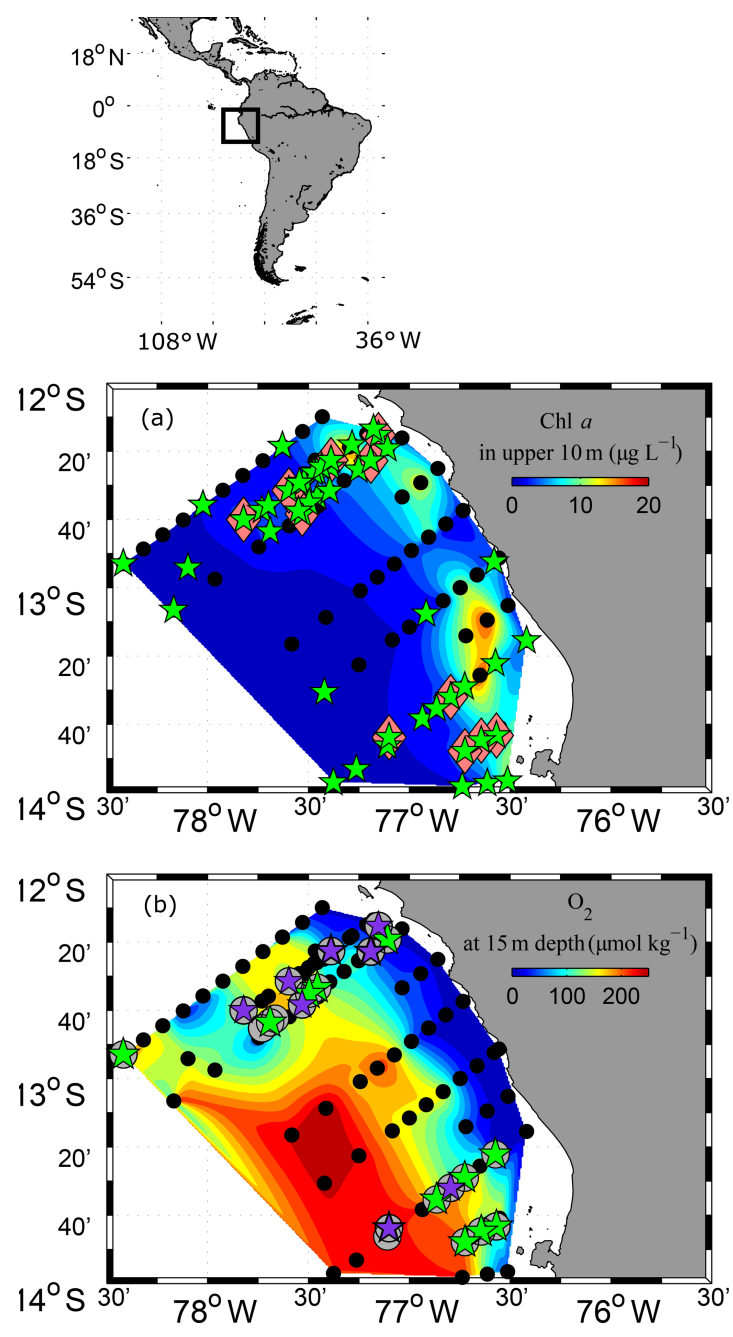

Figure 1. Study area and station map. CTD stations where CTDprobe and fluorimeter measurements were performed are marked as black dots (a, b). PUMP-CTD stations are depicted in pink diamonds (a). CTD and PUMP-CTD stations where DOM sampling was performed are marked as green stars (a). Microstructure measurements combined with oxygen profiles are marked as grey circles (b). Microstructure measurements, combined with dissolved organic matter (dissolved organic carbon (DOC), dissolved hydrolysable amino acids (DHAA) and dissolved combined carbohydrates (DCCHO)) measurements, are marked as green pentagrams (b). Extra microstructure measurements, combined with DOC measurements, are marked with violet pentagrams (b). Shaded colours represent chl $a$ concentrations at upper $10 \mathrm{~m}$ depth (a) and oxygen concentrations at $15 \mathrm{~m}$ depth (b). Spaces between data points were interpolated by using the TriScatteredInterp function (MATLAB, MathWorks).

\subsection{Discrete water sampling and analyses}

Seawater was sampled with a rosette (GO; General Oceanics, USA) equipped with a conductivity, temperature and depth profiler (CTD; Sea-Bird (SBE) 9-plus, Sea-Bird Electronics Inc., USA), an $\mathrm{O}_{2}$ optode (SBE43, Sea-Bird Electronics
Inc., USA), a WETStar chl $a$ fluorometer (WET Labs, USA) and $24 \times 10 \mathrm{~L}$ Niskin bottles. Additional water samples were taken with a PUMP-CTD-System (an integrated measurement device, which was developed in collaboration between the Leibniz Institute for Baltic Research (IOW) and the Max Planck Institute for Marine Microbiology (MPI) Bremen: PUMP-CTD; Strady et al., 2008). In general, samples were collected at three to eight sampling depths from 2 to $70 \mathrm{~m}$ at the onshore stations ( $\sim 10 \mathrm{~km}$ offshore) and from 2 to $200 \mathrm{~m}$ at stations offshore ( $\sim 100 \mathrm{~km}$ offshore). DOC/DON analyses were performed for 49 CTD stations and for 8 PUMPCTD stations. DHAA and DCCHO analyses were performed only for samples from the GO rosette. CTD, $\mathrm{O}_{2}$ and chl $a$ recordings were taken at 172 profiles (Fig. 1a).

The CTD was calibrated with discrete seawater samples measured with a Guildline Autosal 8 model 8400B salinometer. The $\mathrm{O}_{2}$ optode was calibrated by Winkler titration above the oxycline (Winkler, 1888; Hansen, 2007). The STOX sensor measurements, which revealed $\mathrm{O}_{2}$ concentrations of $0.01-0.05 \mu \mathrm{mol} \mathrm{kg}{ }^{-1}$ within the OMZ (Revsbech et al., 2009; Thomsen et al., 2016a), were used for $\mathrm{O}_{2}$ optode calibration at low- $\mathrm{O}_{2}$ levels. The salinity and $\mathrm{O}_{2}$ measurements had a precision of $0.002 \mathrm{~g} \mathrm{~kg}^{-1}$ and $\sim 1 \mu \mathrm{mol} \mathrm{kg}-1$, respectively. More details on the salinity and $\mathrm{O}_{2}$ calibrations can be found in Thomsen et al. (2016a). Apparent oxygen utilization (AOU) was then calculated as a difference of measured $\mathrm{O}_{2}$ concentrations and its equilibrium saturation using the Gibbs-Sea Water Oceanographic Toolbox (McDougall and Barker, 2011) for MatLab (MathWorks, USA) for analyses of potential relationships between DOM reworking and the utilization of $\mathrm{O}_{2}$.

The original fluorometer calibration provided by the sensor manufacturer (WET Labs, USA) was used throughout the cruise, resulting in chl $a$ concentrations in $\mu \mathrm{g} \mathrm{L}^{-1}$. More details on the recalibration of the chl $a$ fluorimeter can be found in Loginova et al. (2016).

Net primary production (NPP) was estimated for the study area off Peru $\left(12-14^{\circ} \mathrm{S}\right.$ and $\left.76-79^{\circ} \mathrm{W}\right)$ and the corresponding time period (February 2013) after the model of Behrenfeld and Falkowski (1997a) with the Ocean Productivity toolbox (Oregon State University).

DOC/DON duplicate samples $(20 \mathrm{~mL})$ were collected into combusted glass ampoules $\left(8 \mathrm{~h}, 450^{\circ} \mathrm{C}\right)$ after filtration with combusted GF/F filters $\left(5 \mathrm{~h}, 450^{\circ} \mathrm{C}\right)$. Samples were acidified $\left(80 \mathrm{~mL}\right.$ of $\left.85 \% \mathrm{H}_{3} \mathrm{PO}_{4}\right)$, sealed with flame and stored at $4^{\circ} \mathrm{C}$ in the dark until analysis. DOC samples were analysed by the high-temperature catalytic oxidation method (TOCVCSH, Shimadzu) using the protocol from Engel and Galgani (2016). The detection limit (DL) was $1 \mu \mathrm{mol} \mathrm{L}^{-1}$. Total dissolved nitrogen (TDN) was determined simultaneously to DOC with a DL of $2 \mu \mathrm{mol} \mathrm{L}^{-1}$ using the TNM-1 detector of a Shimadzu analyser (Dickson et al., 2007). DON concentrations were calculated by subtracting inorganic nitrogen concentrations from concentrations of TDN. The description 

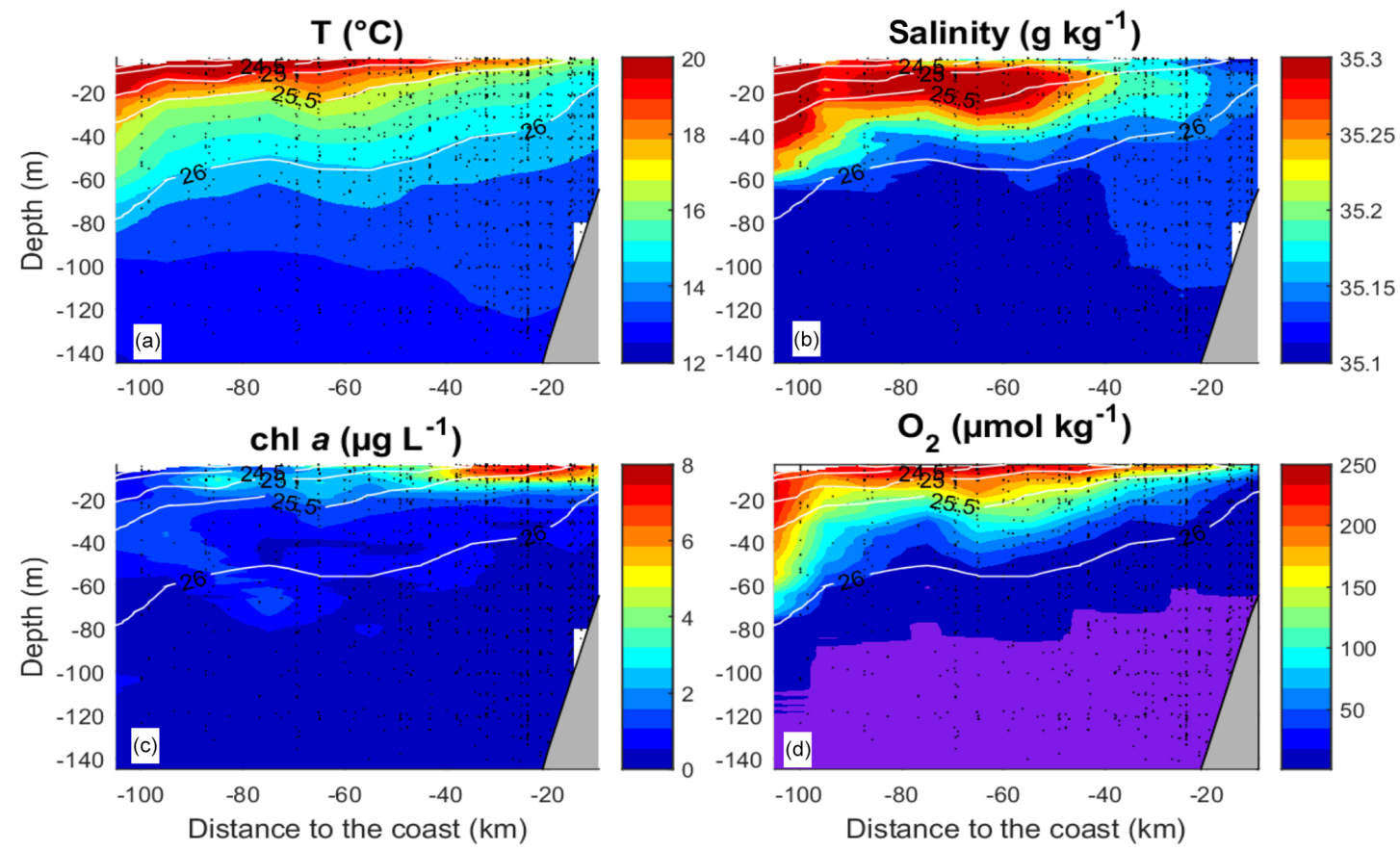

Figure 2. Mean vertical distribution of the temperature (a), salinity (b), (c) chlorophyll $a$ (chl $a$ ) and (d) $\mathrm{O}_{2} . \mathrm{O}_{2}$ values below $1 \mu$ mol kg ${ }^{-1}$ are shaded in violet. The data from all transects and stations were averaged over intervals of $10 \mathrm{~km}$ on the "Distance from the coast" axis and over $1 \mathrm{~m}$ on the "Depth" axis. Isolines represent potential density.

of the instrument calibration and measurements may also be found in Loginova et al. (2015).

Duplicate samples $(\sim 16 \mathrm{~mL})$ for DCCHO were collected into combusted $\left(8 \mathrm{~h}, 450{ }^{\circ} \mathrm{C}\right) 25 \mathrm{~mL}$ glass vials after passing through $0.45 \mu \mathrm{m}$ syringe filters (GHP membrane, Acrodisk, Pall Corporation) and immediately frozen at $-20^{\circ} \mathrm{C}$ until analyses. Analyses were conducted by high-performance anion exchange chromatography (HPAEC) coupled with pulsed amperometric detection following Engel and Händel (2011). Prior to analyses samples were thawed at room temperature and desalinated by membrane dialysis $(1 \mathrm{kDa}$ MWCO, Spectra Por, $5 \mathrm{~h}$ at $1^{\circ} \mathrm{C}$ ). Desalinated duplicate subsamples $(2 \mathrm{~mL}$ ) were hydrolysed using $1.6 \mathrm{~mL}$ of $1 \mathrm{M} \mathrm{HCl}$ (for each) for $20 \mathrm{~h}$ at $100^{\circ} \mathrm{C}$. The hydrolysed samples were neutralized through acid evaporation under $\mathrm{N}_{2}$ atmosphere and an addition of miliQ water $(20 \mathrm{~mL})$. DCCHO monomers were determined from $17.5 \mathrm{~mL}$ subsamples on a Dionex ICS 3000 system. More detailed method and calibration descriptions are given in Engel and Händel (2011). The method precision was $2 \%$ with a DL $\sim 10 \mathrm{nmol} \mathrm{L}^{-1}$. During our study, three classes of polysaccharides were measured. Those were neutral sugars (fucose (Fuc), rhamnose (Rha), arabinose (Ara), galactose (Gal), glucose (Glc), mannose (Man) and xylose (Xyl)), amino sugars (glucosamine (GlcN) and galactosamine (GalN)), and acidic sugars including gluconic acid (GluA) and the uronic acids galacturonic acid (GalUA) and glucuronic acid (GlcUA). Man and Xyl were quantified as a mixture due to co-elution, and, therefore, reported together
(ManXyl). Concentrations of DCCHO after hydrolysis are given as monomer equivalents.

Duplicate samples $(\sim 3 \mathrm{~mL})$ for DHAA were filtered with $0.45 \mu \mathrm{m}$ syringe filters (GHP membrane, Acrodisk, Pall Corporation) and stored frozen $\left(-20^{\circ} \mathrm{C}\right)$ in combusted $\left(8 \mathrm{~h}, 450^{\circ} \mathrm{C}\right) 4 \mathrm{~mL}$ glass vials until analyses. Samples were thawed and hydrolysed with $6 \mathrm{~N} \mathrm{HCl}$ at $100^{\circ} \mathrm{C}$ for $20 \mathrm{~h}$ prior to analysis. DHAA were determined by HPLC after ortho-phthaldialdehyde derivatization (Lindroth and Mopper, 1979; Dittmar et al., 2009) with a DL of $2 \mathrm{nmol} \mathrm{L}^{-1}$ and a precision of $<5 \%$. The following amino acids were analysed during the study: $\alpha$-amino acids: aspartic acid (Asp), glutamic acid (Glu), serine (Ser), arginine (Arg), glycine (Gly), threonine (Thr), alanine (Ala), tyrosine (Tyr), valine (Val), phenylalanine (Phe), isoleucine (Ileu), leucine (Leu); and $\gamma$-amino acid: $\gamma$-aminobutyric acid (GABA). The amino acids asparagine and glutamine likely contributed to the measured Asp and Glu concentrations, respectively, due to deamination during hydrolysis. Alpha aminobutyric acid was used as an internal standard to account for losses during handling. Concentrations of DHAA after hydrolysis are given as monomer equivalents. A more detailed description of the method may be found in Engel and Galgani (2016).

\subsection{Diapycnal flux calculations}

To estimate the diapycnal fluxes of various solutes, CTD sensor $\left(\mathrm{O}_{2}\right)$ and bottle data (DOC, DON, DCCHO and DHAA) 
were combined with near-simultaneous measurements of turbulence in the water column. The turbulence measurements were performed with a microstructure profiling system (MSS) from the rear of the vessel. The loosely tethered profiler (MSS90-D, S/N 32, Sea \& Sun Technology) was optimized to sink at a rate of $0.55 \mathrm{~m} \mathrm{~s}^{-1}$ and was equipped with three shear sensors and a fast-response temperature recorder, as well as an acceleration sensor, two tilt sensors and CTD, sampling with lower response time. At each CTD station, three to six microstructure profiles were collected. Standard processing procedures were used to determine the rate of $\mathrm{ki}$ netic energy dissipation of turbulence in the water column $(\varepsilon$, $\mathrm{m}^{2} \mathrm{~s}^{-3}$ ), as given in Schafstall et al. (2010).

Diapycnal diffusivities $\left(K_{\rho}, \mathrm{m}^{2} \mathrm{~s}^{-1}\right)$ were determined at $14 \mathrm{~m}$ depth intervals, following Osborn (1980):

$K_{\rho}=\Gamma \frac{\varepsilon}{N^{2}}$,

where $N$ is stratification (in $\mathrm{s}^{-1}$ ) and $\Gamma$ is the mixing efficiency, for which a value of 0.2 was used. The diapycnal diffusivity of the solutes $\left(\mathrm{O}_{2}, \mathrm{DOC}, \mathrm{DON}, \mathrm{DCCHO}\right.$, and DHAA) $-K_{\mathrm{S}}-$ was assumed to be equivalent to the diapycnal diffusivity of the mass $K_{\rho}$ (e.g. Schafstall et al., 2010; Fischer et al., 2013).

The diapycnal fluxes $\left(\mathrm{mmol} \mathrm{m}^{-2} \mathrm{~d}^{-1}\right)$ of the different solutes listed above were estimated using Eq. (2), implicitly assuming equivalency of vertical and diapycnal diffusivities $\left(K_{\mathrm{S}} \approx K_{\rho}\right)$.

$\Phi_{\mathrm{S}}=-K_{\rho} \nabla C_{\mathrm{S}}$,

where $\nabla C_{\mathrm{S}}$ is the vertical gradient of the molar concentration of the solutes $\left(\mathrm{mmol} \mathrm{m}^{-4}\right)$.

The mean diapycnal supply $\left(-\overline{\nabla \Phi_{\mathrm{S}}}, \mu \mathrm{mol} \mathrm{kg} \mathrm{kg}^{-1} \mathrm{~d}^{-1}\right)$ of a solute was determined at $28 \mathrm{~m}$ depth intervals as an attenuation of the diapycnal solute flux profile over depth, according to Eq. (3):

$-\overline{\nabla \Phi_{\mathrm{S}}}=-\frac{1}{\rho} \frac{\partial}{\partial z} \overline{\Phi_{\mathrm{S}}}$,

where $\rho$ is the in situ density of the seawater $\left(\mathrm{kg} \mathrm{m}^{-3}\right), z$ is depth $(\mathrm{m})$ and $\overline{\Phi_{\mathrm{S}}}\left(\mathrm{mmol} \mathrm{m} \mathrm{m}^{-2} \mathrm{~d}^{-1}\right)$ is the estimated mean diapycnal flux profile of a solute. The mean diapycnal solute supply was interpreted to balance the amount of a solute that is lost per unit of time over a specific depth interval of the water column due to the microbial utilization of the solute. This interpretation assumes that sources other than turbulent mixing or sinks other than microbial consumption are negligible.

For DCCHO and DHAA the diapycnal flux estimates were based on 14 combined CTD/MSS stations, while for DOC and DON fluxes 22 stations were available (Fig. 1b). The diapycnal $\mathrm{O}_{2}$ flux was determined from 50 combined stations. All combined data sets include stations from the continental slope, as well as stations in deeper waters, where bottom depth was larger than $4000 \mathrm{~m}$.
For each combined CTD/MSS station a mean $K_{\rho}$ was estimated based on a $N^{2}$ profile (CTD) and mean dissipation profile (turbulence probe) averaged over all MSS profiles conducted at the CTD station. In combination with the vertical solute gradient, a mean flux profile for each station was estimated. Only measurements below the mixed layer, which was defined by a threshold criterion of a $0.2{ }^{\circ} \mathrm{C}$ temperature decrease below the maximum and a minimum depth of $10 \mathrm{~m}$, were used. Measurements from different sensors and instruments were averaged in temperature space to reduce the impact of internal waves.

The mean diapycnal flux $\left(\overline{\Phi_{\mathrm{S}}}\right)$ was determined by arithmetically averaging all fluxes from individual stations in $14 \mathrm{~m}$ depth intervals. The diapycnal solute supply was then determined from the divergence of the mean diapycnal flux $\left(\overline{\nabla \Phi_{\mathrm{S}}}\right)$.

The $95 \%$ confidence interval of the diapycnal flux was calculated following the procedure described by Schafstall et al. (2010). From this error estimate the uncertainty of the supply was derived by error propagation.

A simple equation of carbon combustion,

$1 \mathrm{C}+1 \mathrm{O}_{2}=1 \mathrm{CO}_{2}$,

was used for a rough estimation of the percentage of diapycnal $\mathrm{O}_{2}$ supply that may be consumed by heterotrophic communities, if they use all the $\mathrm{C}$, supplied by the diapycnal fluxes of DOC, DCCHO and DHAA.

\subsection{Statistical analyses of DOM composition}

Principal component analysis (PCA) was performed using environmental factors (temperature, salinity and $\mathrm{AOU}$ ) and relative abundances of $\alpha$-DHAA and neutral DCCHO (mol\%) to examine "compositional trends" (i.e. changes in composition in response to an influence of an environmental parameter) in marine DOM in the studied area. The aim of the PCA was also to explore the potential interrelation between low- $\mathrm{O}_{2}$ and DOM composition. For this, temperature, salinity and AOU and relative abundances of labile organic matter from the open Atlantic and Pacific oceans (Kaiser and Benner, 2009) were included in the PCA for the representation of a well-oxygenated water column. The covariance between principle components and an individual parameter was considered significant when the module of the coordinate of the parameter exceeded 0.5 on the "variables factor map". The PCA was performed using the "FactorMineR" package (Husson et al., 2010) for "R" (R Core Team, 2013).

\section{Results}

\subsection{Distribution of $\mathrm{O}_{2}$ and DOM}

In this section the horizontal and vertical distributions of $\mathrm{O}_{2}$ and the different DOM components including DOC, DON 
and their labile and semi-labile constituents, DCCHO and DHAA, are described. The vertical gradients of the different solutes are crucial for estimating the associated diapycnal fluxes, as described in Sect. 3.2. Near-surface $\mathrm{O}_{2}$ concentrations were observed, ranging between $100 \mu \mathrm{mol} \mathrm{kg}-1$ at the coast and $240 \mu \mathrm{mol} \mathrm{kg}{ }^{-1}$ further offshore (Fig. 2d). These values dropped to less than $1 \mu \mathrm{mol} \mathrm{kg}-1$ at $<50 \mathrm{~m}$ depth near the coast $(<40 \mathrm{~km}$ offshore) and $\sim 80 \mathrm{~m}$ depth offshore ( $>40 \mathrm{~km})$ (Fig. 2d).

DOC concentrations ranged from more than $100 \mu \mathrm{mol} \mathrm{L}^{-1}$ near the surface to $<50 \mu \mathrm{mol} \mathrm{L}^{-1}$ below $40 \mathrm{~m}$ depth (Fig. 3a). Patches of isolated DOC maxima (up to $120 \mu \mathrm{mol} \mathrm{L}^{-1}$ ) were measured at a depth range from 20 to $120 \mathrm{~m}$ (Fig. 3a). DOC concentrations of $>100 \mu \mathrm{mol} \mathrm{L}^{-1}$ had been reported previously for the water column off Peru (Romankevich and Ljutsarev, 1990; Franz et al., 2012a). However, since concentrations $>100 \mu \mathrm{mol} \mathrm{L}^{-1}$ were observed only sporadically, we cannot exclude a possible contamination of these samples. The main decrease in DOC occurred between 5 and $30 \mathrm{~m}$. Thus, the main vertical DOC gradient was found at shallow depth compared to the oxycline. This becomes even more apparent when comparing the mean vertical profiles of $\mathrm{O}_{2}$ and DOC (Fig. 4a, b).

DON concentrations were also highest $\left(\sim 7-8 \mu \mathrm{mol} \mathrm{L}^{-1}\right)$ near the surface (Fig. 3b) and varied from below detection to $4-5 \mu \mathrm{mol} \mathrm{L}^{-1}$ at greater depth. The main decrease in DON concentrations occurred within the upper $10 \mathrm{~m}$ of the water column (Fig. 4c).

DCCHO concentrations varied from 0.2 to $4.2 \mu \mathrm{mol} \mathrm{L}^{-1}$ (Fig. 3c), with the highest concentrations near the surface. C contained in DCCHO represented 1 to a maximum of $25 \%$ of DOC in the studied depth range. Amino sugars were represented solely by GlcN, as GalN was below DL in most samples. Acidic sugars were mainly represented by uronic sugars, i.e. GluUA and GalUA (Table 1), while GlcA was detected only sporadically. Overall, amino sugars and acidic sugars comprised $0.04 \pm 0.03$ and $0.02 \pm 0.02 \mu \mathrm{mol} \mathrm{L}^{-1}$, contributing $6 \pm 3 \%$ and $3 \pm 2 \%$ to DCCHO, respectively. Thus, the major part of DCCHO was represented by neutral sugars (Table 1). DHAA concentrations varied from 0.075 to $1.39 \mu \mathrm{mol} \mathrm{L}^{-1}$ (Fig. 3d). Like for DCCHO, the highest DHAA concentrations were found above the oxycline, where $\mathrm{C}$ contained in DHAA represented $2 \pm 1 \%$ DOC (maximum of $4 \%$ ) and nitrogen $(\mathrm{N})$ contained in DHAA represented $15 \pm 14 \% \mathrm{DON}$. The lowest DHAA concentrations were mainly found below $80 \mathrm{~m}$ depth and were equivalent to $\sim 1 \% \mathrm{DOC}$ and $6 \% \mathrm{DON}-8 \% \mathrm{DON}$ (Table 1). The major part of DHAA was represented by $\alpha$-amino acids. The concentrations of GABA, which is commonly used as a signature of microbial activity (Davis et al., 2009), was very low in all samples and represented generally $<1 \%$ of DHAA. In summary, the concentrations of all the DOM compounds were highest above the oxycline and the mean concentration gradients of the DOM compounds were restricted to a shallower depth compared to the mean gradient of $\mathrm{O}_{2}$ (Fig. 4).

\subsection{Diapycnal fluxes and supply}

As outlined in the previous section, vertical gradients of $\mathrm{O}_{2}$, DOC, DON and their constituents were observed at 10 to $80 \mathrm{~m}$ depth in the study area. In this section we combine these vertical gradients with turbulence measurements to estimate the associated diapycnal fluxes and supply, i.e. the diapycnal flux divergences.

For $\mathrm{O}_{2}$, the mean diapycnal flux $\left(\overline{\nabla \Phi_{\mathrm{O}_{2}}}\right)$ exhibited a maximum of $50 \mathrm{mmol} \mathrm{O}_{2} \mathrm{~m}^{-2} \mathrm{~d}^{-1}$ at $\sim 20 \mathrm{~m}$ depth. It decreased deeper in the water column and vanished at $80 \mathrm{~m}$ depth due to a lack of vertical concentration gradients. Onshore $(<40 \mathrm{~km})$ and offshore ( $>40 \mathrm{~km}$ ) $\mathrm{O}_{2}$ fluxes did not differ statistically. This likely was due to the fact that while vertical oxygen gradients were enhanced in the offshore region (Fig. 4a), the turbulence and, thus, eddy diffusivities were elevated in the onshore region. The mean diapycnal supply $\mathrm{O}_{2}\left(\overline{\nabla \Phi_{\mathrm{O}_{2}}}\right)$ ranged from $1.2 \mu \mathrm{mol} \mathrm{kg}{ }^{-1} \mathrm{~d}^{-1}$ at $10-24 \mathrm{~m}$ depth to near zero at $80 \mathrm{~m}$ depth (Table 2). Again, onshore $(<40 \mathrm{~km})$ and offshore $(>40 \mathrm{~km})$ the diapycnal $\mathrm{O}_{2}$ supply was not statistically different.

In contrast, mean diapycnal fluxes of DOC $\left(\overline{\Phi_{\mathrm{DOC}}}\right)$ were limited to shallower depth. Near the surface, $\overline{\Phi_{\mathrm{DOC}}}$ was $31 \mathrm{mmol} \mathrm{C} \mathrm{m}^{-2} \mathrm{~d}^{-1}$ and vanished already at $\sim 50 \mathrm{~m}$ depth (Table 2$)$. The diapycnal supply of DOC $\left(\overline{\nabla \Phi_{\text {DOC }}}\right)$ exhibited a maximum of $1.8 \mu \mathrm{mol} \mathrm{C} \mathrm{kg}^{-1} \mathrm{~d}^{-1}$ at $10-38 \mathrm{~m}$ depth $(1.5$ times larger than $\overline{\nabla \Phi_{\mathrm{O}_{2}}}$ ) (Table 2, Eq. 4). Compared to NPP, estimated to $3.9(0.6-8.6) \mathrm{gC} \mathrm{m}^{-2} \mathrm{~d}^{-1}$ for our study area and period, the DOC flux represented a maximum of $\sim 10 \% \mathrm{NPP}$ at $\sim 20 \mathrm{~m}$ depth to near zero $\% \mathrm{NPP}$ at $\sim 50 \mathrm{~m}$ depth. As was mentioned in Sect. 3.1, we did not find a vertical DON gradient, resulting in very low diapycnal DON fluxes and supply estimates (Table 2). However, $\mathrm{N}$ fluxes were obtained from DHAA transport. Mean $\mathrm{C}$ and $\mathrm{N}$ fluxes via DCCHO and DHAA ranged from near zero below $30-40 \mathrm{~m}$ depth to $6 \mathrm{mmol} \mathrm{C} \mathrm{m}^{-2} \mathrm{~d}^{-1}\left(\overline{\left.\Phi_{\mathrm{DCCHO}(\mathrm{C})}\right)}, 0.9 \mathrm{mmol} \mathrm{C} \mathrm{m}^{-2} \mathrm{~d}^{-1}\right.$ $\left(\overline{\Phi_{\operatorname{DHAA}(\mathrm{C})}}\right)$ and $0.3 \mathrm{mmol} \mathrm{N} \mathrm{m}^{-2} \mathrm{~d}^{-1}\left(\overline{\Phi_{\mathrm{DHAA}(\mathrm{N})}}\right)$ at 10 $20 \mathrm{~m}$ depth (Table 2). The diapycnal $\mathrm{C}$ and $\mathrm{N}$ supply via DC$\mathrm{CHO}$ and DHAA ranged from near zero to a maximum of $0.4 \mu \mathrm{mol} \mathrm{C} \mathrm{kg}{ }^{-1} \mathrm{~d}^{-1}\left(\overline{\nabla \Phi_{\mathrm{DCCHO}(\mathrm{C})}}\right), 0.06 \mu \mathrm{mol} \mathrm{C} \mathrm{kg}^{-1} \mathrm{~d}^{-1}$ $\left(\overline{\left.\nabla \Phi_{\operatorname{DHAA}(\mathrm{C})}\right)}\right.$, and $0.02 \mu \mathrm{mol} \mathrm{N} \mathrm{kg}{ }^{-1} \mathrm{~d}^{-1}\left(\overline{\left.\nabla \Phi_{\operatorname{DHAA}(\mathrm{N})}\right)}\right)$ at $10-38 \mathrm{~m}$ depth. The diapycnal $\mathrm{C}$ supply via DCCHO and DHAA at its maximum comprised $\sim 38 \%$ of $\overline{\nabla \Phi_{\mathrm{O}_{2}}}$, when estimated by Eq. (4). In summary, our diapycnal flux and supply calculation revealed that the diapycnal $\mathrm{O}_{2}$ supply reaches deeper into the oxycline than the diapycnal DOM supply. This is especially true for DCCHO and DHAA, representing the labile and semi-labile parts of DOM.

\subsection{Linking the DOM composition and the utilization of $\mathrm{O}_{2}$}

To understand whether low- $\mathrm{O}_{2}$ conditions of the OMZ may cause changes in DOM composition, we complement our quantitative estimates of the DOM and $\mathrm{O}_{2}$ supply with the 


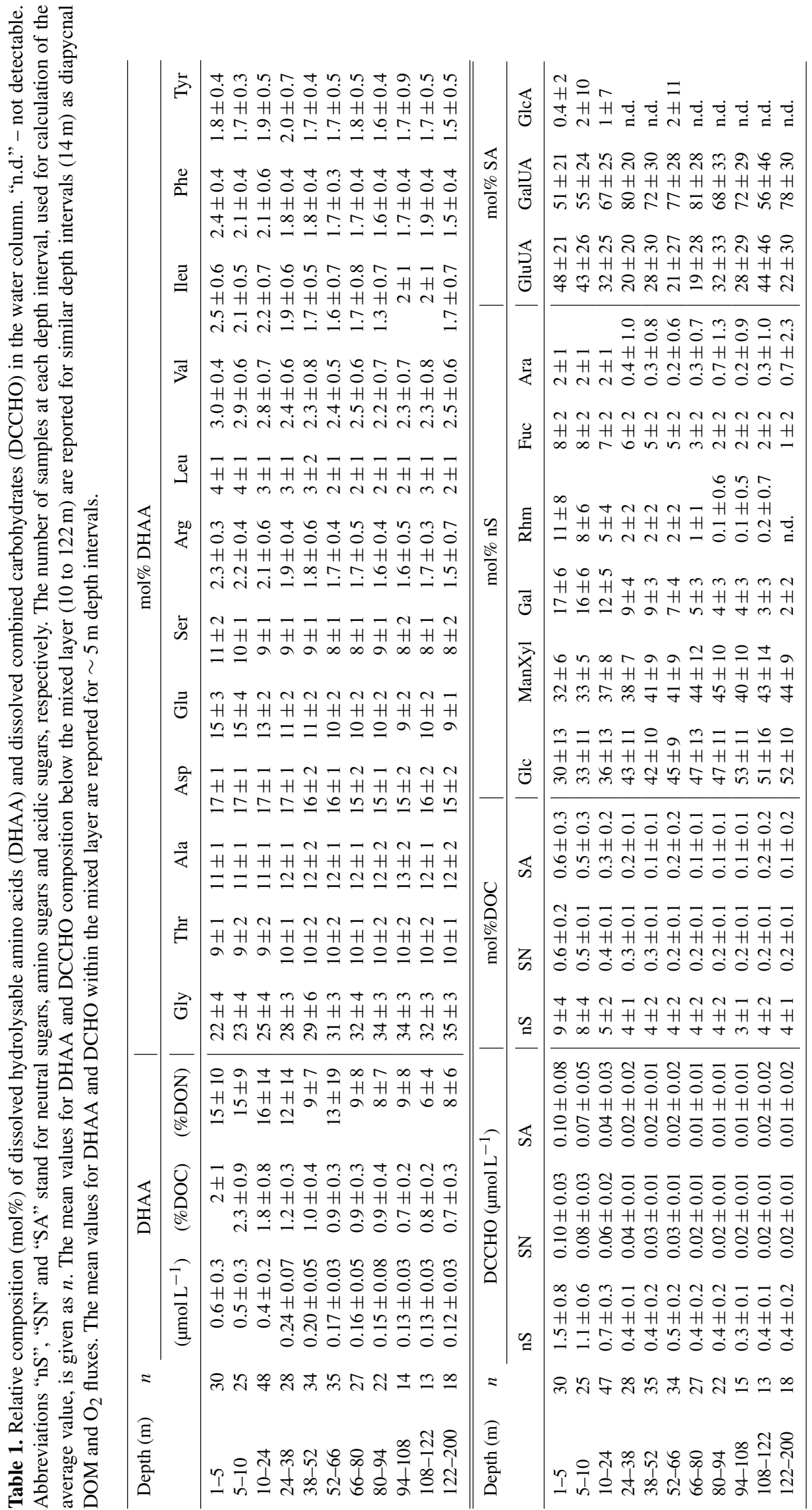



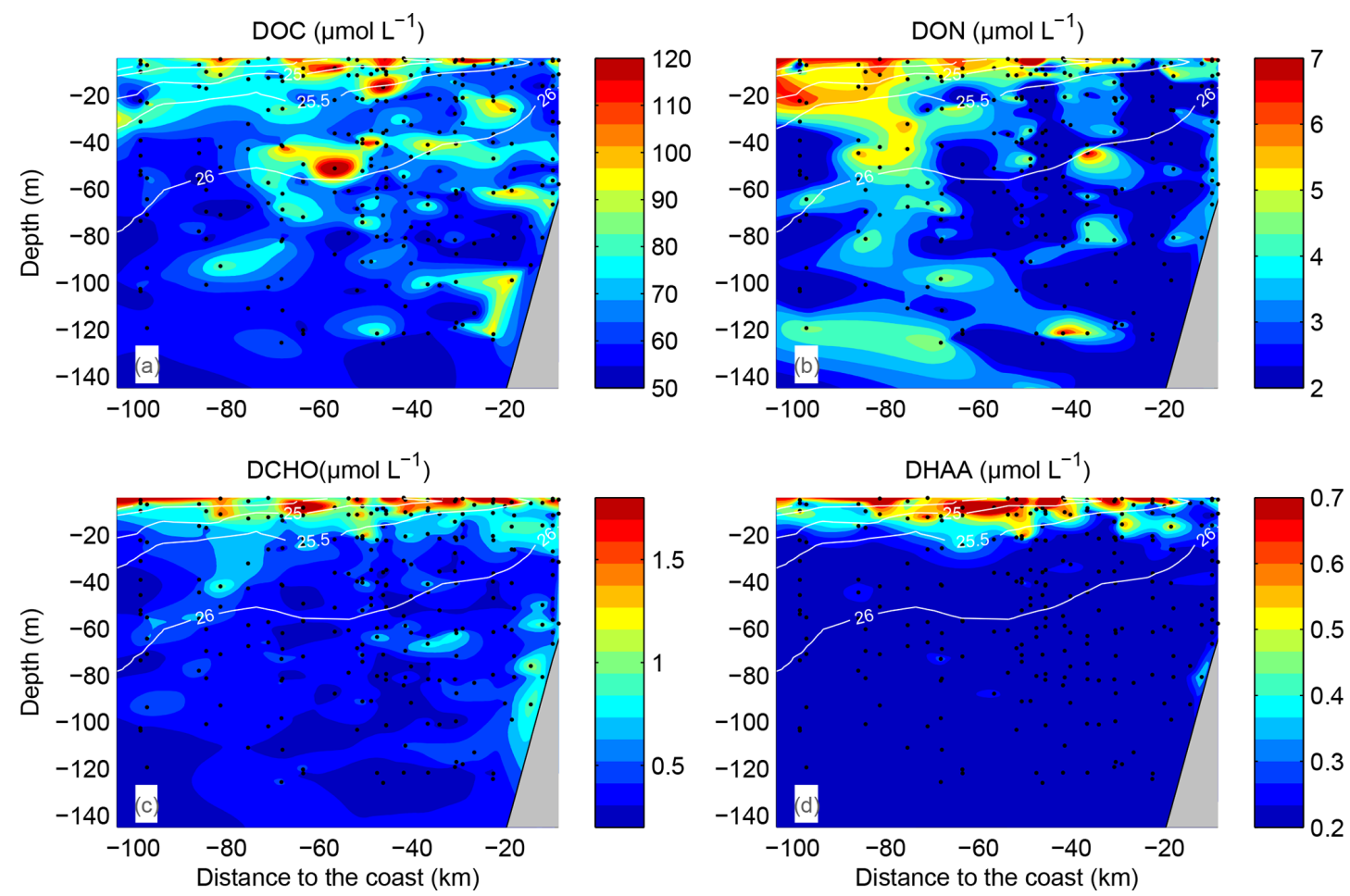

Figure 3. Dissolved organic carbon (DOC) (a), dissolved organic nitrogen (DON) (b), dissolved combined carbohydrates (DCCHO) (c) and dissolved hydrolysable amino acids (DHAA) (d) distributions over the water column. Data from all transects and stations were plotted against distance to coast (kilometres). Space between data points was interpolated by using the TriScatteredInterp function (MATLAB, MathWorks). Isolines represent potential density, averaged over intervals of $10 \mathrm{~km}$ on the "Distance from the coast" axis and over $1 \mathrm{~m}$ on the "Depth" axis.
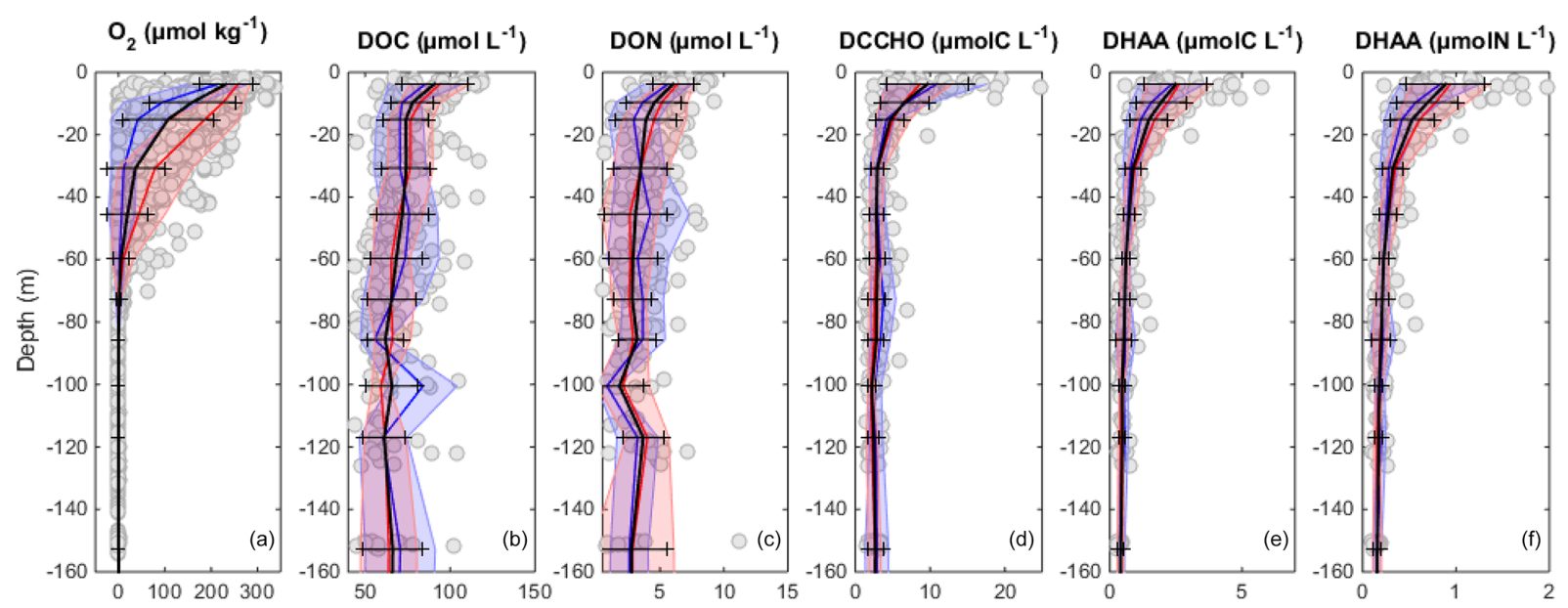

Figure 4. Vertical distribution of $\mathrm{O}_{2}(\mathbf{a}), \operatorname{DOC}(\mathbf{b}), \operatorname{DON}(\mathbf{c}), \operatorname{DCCHO}(\mathrm{C})(\mathbf{d}), \operatorname{DHAA}(\mathrm{C})(\mathbf{e})$, and DHAA(N) (f). Black line and error bar represent mean distribution and standard deviations of the data points (grey circles), respectively. The blue and red lines and shaded areas represent the mean distributions and standard deviations of parameters onshore $(<40 \mathrm{~km})$ and offshore $(>40 \mathrm{~km})$, respectively.

analyses of DOM quality. For this, the composition of neutral DCCHO and DHAA via PCA was compared to environmental factors, i.e. temperature, AOU and salinity, and to organic matter composition from the well-oxygenated water column as described in Kaiser and Benner (2009). The first principle component (Dim.1) (Fig. 5, "variables factor map") of the PCA was strongly influenced by AOU, indicating the interrelation of the DOM composition and removal of $\mathrm{O}_{2}$. The utilization of $\mathrm{O}_{2}$ was accompanied by selective removal of Glu, Phe, Leu, ILeu and Ser, and Rha, Gal, and Fuc (Fig. 5, Table 1). Gly, Thr and Glc mol\% were increasing along with an increase in AOU (Fig. 5). In general, the composition of 
Table 2. Diapycnal fluxes and supplies of $\mathrm{O}_{2}$ and DOM: DOC, DON, dissolved organic carbon in DCCHO and DHAA and dissolved organic nitrogen in DHAA; $95 \%$ confidence intervals, calculated following Schafstall et al. (2010) for each parameter, are presented in brackets. BLM - "below the mixed layer" - a depth, defined below $10 \mathrm{~m}$ of the water column, using a threshold criterion of $0.2^{\circ} \mathrm{C}$ temperature decrease.

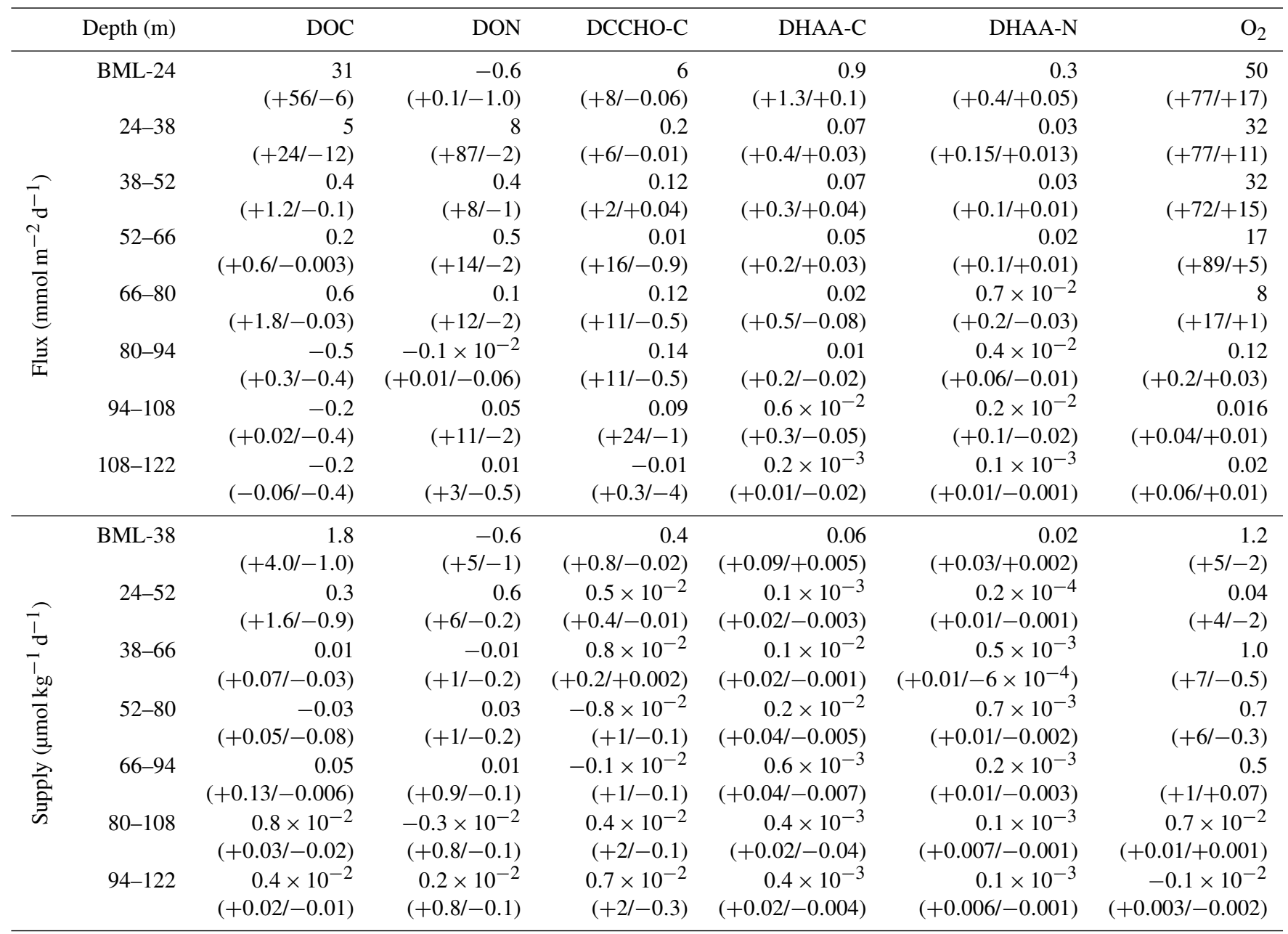

DOM from the surface samples from our study was similar to the composition of DOM from the samples, collected from well-oxygenated open ocean sites by Kaiser and Benner (2009), as the individual scores of the samples cluster together on Dim.1 of the PCA (Fig. 5, "individuals factor map"). The samples collected within the OMZ were much poorer in composition, even in comparison to the deepest open ocean samples $(\sim 4000 \mathrm{~m})$, as they grouped from the negative side of Dim.1.

The differences on the second dimension of PCA (Dim.2) were driven likely by regional differences in the DOM composition, i.e. by mol\% of Ala, Arb, and Fuc, and distributions of mol\% Asp, Phe, Val and Leu over depth (Fig. 5, Table 1, Kaiser and Benner, 2009).

\section{Discussion}

The observed distributions of $\mathrm{O}_{2}$ and of DOC and DON components are the result of sinks and sources in the water column mainly due to microbial processes and isopycnal and diapycnal supply (i.e. flux divergences) controlled by physical processes. A quantification of each of those individual processes is essential for understanding of important mechanisms controlling $\mathrm{O}_{2}$ and organic matter cycling off Peru and, therefore, the formation and maintenance of the Peruvian OMZ.

Previous studies have shown that turbulent mixing processes in the eastern boundary upwelling systems (EBUS) are strongly enhanced and that the resulting diapycnal supply is often a leading term in the flux divergence balances of $\mathrm{O}_{2}$, nutrients and other solutes in the upper ocean (e.g. Schafstall et al., 2010; Kock et al., 2012; Brandt et al., 2015; Steinfeldt et al., 2015). 
(a)

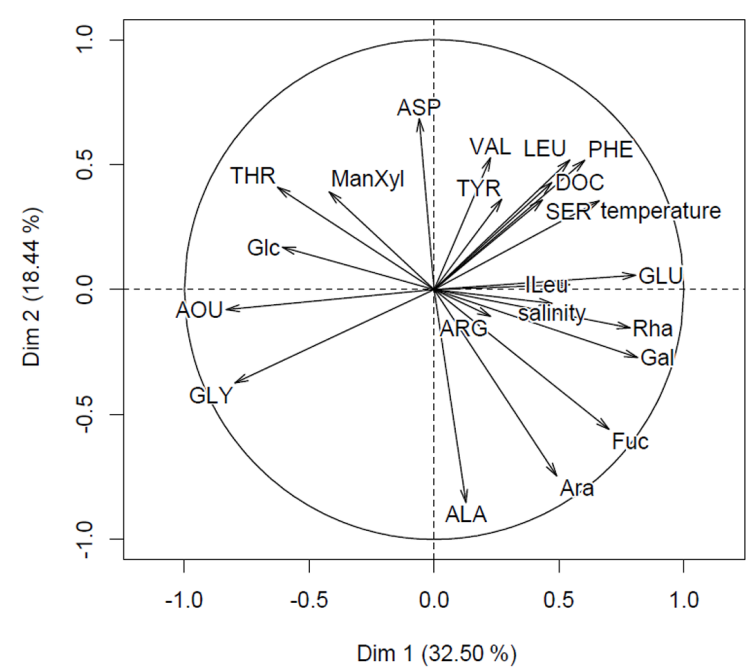

(b)

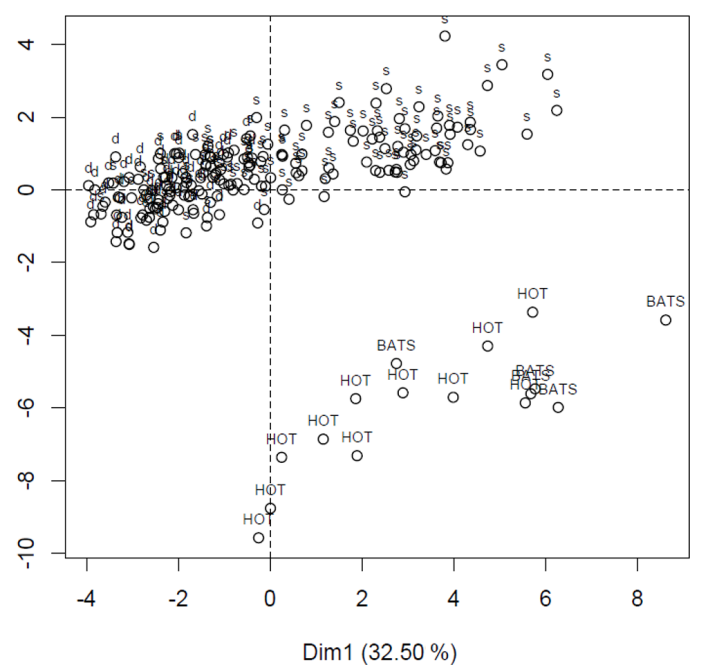

Figure 5. The PCA output: variables (a) and individual scores of samples (b). The samples, collected above $50 \mathrm{~m}$ depth, are marked with abbreviation "s", the ones below $50 \mathrm{~m}$ depth with abbreviation " $\mathrm{d}$ ". The samples, which are used for comparison, are marked with acronyms "HOT" and "BATS", and represented well-oxygenated samples collected from the open Pacific and open Atlantic oceans, respectively (Kaiser and Benner, 2009).

The diapycnal $\mathrm{O}_{2}$ and DOM fluxes and supply determined in this study represent average values for the continental margin ranging from the shelf to about $100 \mathrm{~km}$ offshore. This spatial averaging is likely responsible for a lower nearsurface diapycnal $\mathrm{O}_{2}$ flux $\left(50 \mathrm{mmol} \mathrm{O}_{2} \mathrm{~m}^{-2} \mathrm{~d}^{-1}\right)$ compared to other EBUS. For example, Brandt et al. (2015) determined a near-surface diapycnal $\mathrm{O}_{2}$ flux of $73 \mathrm{mmol} \mathrm{O}_{2} \mathrm{~m}^{-2} \mathrm{~d}^{-1}$ in the Mauritanian upwelling during the high-productivity season in boreal winter. In their study, the diapycnal $\mathrm{O}_{2}$ flux was able to sustain benthic respiration on the continental shelf down to a bottom depth of $100 \mathrm{~m}$. Herewith, the diapycnal $\mathrm{O}_{2}$ supply found in our study was of similar magnitude to the rates of $\mathrm{O}_{2}$ consumption $\left(\sim 1 \mu \mathrm{mol} \mathrm{kg}{ }^{-1} \mathrm{~d}^{-1}\right)$ determined by in situ incubations at $50-80 \mathrm{~m}$ water depth during the austral summer season in the ETSP off Peru (Kalvelage et al., 2015) and similar estimates for North and South Pacific OMZs (Revsbech et al., 2009; Tiano et al., 2014).

Other terms of the $\mathrm{O}_{2}$ transport budget such as isopycnal supply by mesoscale (Thomsen et al., 2016a) and submesoscale (Thomsen et al., 2016b) dynamics or fluxes due to upwelling (e.g. Steinfeldt et al., 2015) might play an important role for the distribution of $\mathrm{O}_{2}$ in the upper ocean, particularly in the region of the continental slope and the shelf. In turn, the deep chl $a$ maximum formed by photosynthetic cyanobacteria, i.e. Prochlorococcus, that have been found in the ETSP (Lavin et al, 2010; Ulloa et al., 2012; Meyer et al., 2017) may provide an additional $\mathrm{O}_{2}$ source at depth. Furthermore, the presented diapycnal fluxes and supply of $\mathrm{O}_{2}$ were determined from the data collected during ocean settings typical of the austral summer season of non-El Niño/La Niña years. In the water column, $\mathrm{O}_{2}$ concentrations and back- ground settings for the production of turbulence were shown to vary substantially on seasonal and interannual timescales (e.g. Graco et al., 2017). Thus, the diapycnal fluxes and supply of $\mathrm{O}_{2}$ shall vary on the same timescales. Therefore, our results should be considered the first estimates of diapycnal $\mathrm{O}_{2}$ fluxes and supply in the ETSP off Peru during the austral summer season during non-El Niño/La Niña regime.

Like for $\mathrm{O}_{2}$, the transport of DOM through the water column is achieved by advective and diffusive transport processes. Therefore, along with turbulent mixing, other transport terms will also take their turn in shaping the DOM distribution off Peru. For instance, vertical advection (i.e. upwelling) transports deep water, which is characterized by highly altered DOM and low DOC concentrations, into the upper ocean near the continental margins. The upwelling may counteract the turbulent downward flux of DOC and, therefore, contribute to a "compression" or sharpening of the vertical DOM concentration and composition profiles. This is unique to upwelling systems and different to the open ocean regions where low-DOC concentration gradients and smaller changes in the DOM composition were observed at similar depth (Kaiser and Benner, 2009). Additionally, mesoscale (Thomsen et al., 2016a) and submesoscale (Thomsen et al., 2016b) dynamics have been observed in the studied area. They were shown to modify nutrient and $\mathrm{O}_{2}$ distributions by stirring the water across the continental slope, and likely influence the DOM distribution off Peru too. However, no quantitative information on DOM fluxes associated with upwelling, mesoscale or submesoscale dynamics off Peru is available to date. Seasonal and interannual variations in physical dynamics may also affect DOM distribution off 
Peru; e.g. deepening of the mixed layer during austral winter (Echevin et al., 2008) or intense downwelling/upwelling during El Niño/La Niña events (e.g. Graco et al., 2017) may result in the diapycnal DOM supply to a different depth than during a typical austral summer season.

DOM might also be transported to depth within particles. Thus, the "uncoupled" dissolution of large sinking aggregates as a result of bacterial enzymatic activity (Smith et al., 1992) or abiotically (Sempéré et al., 2000) may serve as an additional DOM source and, therefore, affect the distribution of DOM in the water column. The sporadic dissolution of particles may bias the diapycnal DOM flux estimates at individual stations. Therefore, the bias may be reduced by calculating the mean diapycnal flux over a large number of depth profiles. The continuous DOM release from POM over the water column (e.g. Lefévre et al., 1996), in turn, may lead to an overestimation of diapycnal DOM fluxes and DOM-based microbial respiration. However, no direct measurements of the DOM fraction resulting from particle dissolution exist so far in the studied area.

Furthermore, DOM is affected by other abiotic or biological processes in the water column. For instance, the observed very low diapycnal DON flux may suggest a DON removal in the upper water column. Low concentrations of inorganic nutrients above $20 \mathrm{~m}$ depth (Thomsen et al., 2016a), and an overall nitrogen limitation that was found to be characteristic of the surface communities in the ETSP off Peru (Franz et al., 2012b), might force those communities to switch to organic nitrogen sources (e.g. Bradley et al., 2010), therefore reducing DON in the upper water column. Photoreactions could also reduce DON incorporated into large chromophoric molecules through production of volatile $\mathrm{N}$ compounds or inorganic N (Zepp et al., 1998). Thus, DOM composition was suggested to be affected by the photochemistry in our study area (Galgani and Engel, 2016; Loginova et al., 2016). Photochemical degradation to $\mathrm{CO}, \mathrm{CO}_{2}$ and other volatile compounds (Zepp et al., 1998) could lower the nearsurface diapycnal DOC flux, as well.

Herewith, our data suggest that the diapycnal DOC flux in the upper $20 \mathrm{~m}$ of the water column off Peru is of the same order of magnitude as the diapycnal $\mathrm{O}_{2}$ flux (Table 2). The annual diapycnal DOC flux $\left(2.7 \mathrm{~mol} \mathrm{C} \mathrm{m}^{-2} \mathrm{yr}^{-1}\right)$ into the upper OMZ, estimated from our results by averaging $\overline{\Phi_{\mathrm{DOC}}}$ above the mean depth of the oxycline (from below the mixed layer to $80 \mathrm{~m}$ depth) and integrating over a year, is of the same order of magnitude as previously reported data for the North Pacific Subtropical Gyre, where DOC export was estimated by a mass balance approach $\left(1.6-2.7 \mathrm{~mol} \mathrm{C} \mathrm{m}^{-2} \mathrm{yr}^{-1}\right.$; Emerson et al., 1997) and by fitting an exponential decay function over depth $\left(0.5 \pm 0.1 \mathrm{~mol} \mathrm{C} \mathrm{m}^{-2} \mathrm{yr}^{-1}\right.$; Kaiser and Benner, 2012). Compared to NPP, the diapycnal DOC flux ( $\sim 10 \% \mathrm{NPP}$ ) was comparable to the POC export, previously reported for the upper water column in the ETSP off Chile ( $\sim 12 \%$ NPP (30 m depth), Pantoja et al., 2004) and in the ETSP off Peru ( $\sim 6 \%$ NPP (52 m depth); Gagosian et al.,
$1983 ; 16 \%-42 \%$ NPP (near the surface); Kalvelage et al., 2013), suggesting turbulent mixing of DOM as an important $\mathrm{C}$ export mechanism in the upper oxycline.

Furthermore, in the upper water column (from below the mixed layer to $38 \mathrm{~m}$ water depth), the diapycnal DOC supply was higher than the diapycnal $\mathrm{O}_{2}$ supply, suggesting that DOC respiration could exhaust all $\mathrm{O}_{2}$. However, the vanishing of DOC flux above the upper oxycline suggests that the bioavailable fraction of DOM is respired well before entering the upper OMZ. This is even more apparent when considering diapycnal DHAA and DCCHO fluxes, which decayed more rapidly compared to the diapycnal DOC flux, suggesting preferential uptake of DHAA and DCCHO in the water column. The diapycnal supply of DHAA and DCCHO could not fully explain the diapycnal supply of DOC, as those were responsible for only $\sim 26 \%$ of $\overline{\nabla \Phi_{\mathrm{DOC}}}$ when summed up together. This may hint at a presence of an additional bioavailable DOM component that was respired in the water column and/or to other DOM removal mechanisms in the near-surface waters. For instance, DOM may form marine microgels and hence POM (Chin et al., 1998; Engel et al., 2004; Verdugo et al., 2004) or be trapped in the pore space of already existing particles (e.g. Benner, 2002).

As DHAA and DCCHO are preferentially utilized during microbial decomposition of organic matter (Skoog and Benner, 1997; Lee et al., 2000; Amon et al., 2001), their carbon yield (\%DOC) and composition may serve as indicators of the diagenetic history of DOM (e.g. Kaiser and Benner, 2009; Davis et al., 2009). Thus, the relatively high carbon yield of DHAA and DCCHO (Table 1), found near the surface during our study, suggests that DOM in surface waters off Peru is more bioavailable compared to the open ocean (Davis and Benner, 2007; Kaiser and Benner, 2009). It is, however, rapidly altered at shallow depth. Applying the classification of Davis and Benner (2007), which implies that carbon yields of DHAA above $1.6 \%$ DOC and $1.09 \% \mathrm{DOC}$ correspond to labile and semi-labile DOM, respectively, to our data suggests that the labile and semi-labile DOM off Peru was restricted to the upper $50 \mathrm{~m}$ of the water column.

The compositional analyses of DHAA and DCCHO suggested preferential microbial uptake of Glu, Phe, Ser, Leu, Rha, Gal, Fuc, and Ara in the near-surface waters, as below $50 \mathrm{~m}$ depth, the compositions of DHAA and DCCHO were dominated by Gly and Glc, respectively (Fig. 5, Table 1). Glc was previously suggested to be less susceptible to microbial degradation compared to preferentially removed Fuc, Gal, and Ara (Ittekot et al., 1981; Sempéré et al., 2008; Goldberg et al., 2010; Engel et al., 2012). Enrichment in Gly with depth has also been proposed to reflect the low nutritional value of Gly in anoxic sediments off Chile (Pantoja and Lee, 2003) and in sediments of the North Sea (Dauwe and Middelburg, 1998). Therewith, our data suggest that DOM in the shallow OMZ off Peru was characterized by stronger alteration compared to open-ocean samples (Kaiser and Benner, 2009) at even much greater depths (up to $4000 \mathrm{~m}$ ). This may 
be due to both an upwelling of altered DOM from the deep and a rapid and very extensive heterotrophic DOM utilization in the ETSP. The upwelling may "compress" labile and semilabile DOM towards the surface, while the rapid microbial utilization of DOM will prevent labile and semi-labile DOM export into the OMZ, and also would imply a pronounced heterotrophic respiration. The latter was suggested by our PCA analyses, as DOM composition was highly interrelated to AOU. Herewith, the diapycnal supply of DHAA and DC$\mathrm{CHO}$ could explain up to $38 \%$ of $\overline{\nabla \Phi_{\mathrm{O}_{2}}}$. This suggests that despite the diapycnal fluxes of labile and semi-labile fractions of DOM not reaching deep into the core of the OMZ, DOM-based microbial respiration above the OMZ may substantially attenuate the diapycnal $\mathrm{O}_{2}$ flux that ventilates the upper oxycline. In other words, DOM may alter the shape of the upper oxycline and, therefore, contribute to the formation and maintenance of the OMZ.

\section{Conclusions}

Our results suggest that DOM, i.e. DCCHO and DHAA, is significantly consumed and altered above the upper oxycline in the ETSP off Peru. Thus, despite the presence of high DOC concentrations in the euphotic zone, DOM may enter the OMZ in an already highly reworked stage. Herewith, DOM respiration may contribute substantially $(\sim 38 \%)$ to $\mathrm{O}_{2}$ reduction in the upper water column, potentially controlling the shape of the upper oxycline of the OMZ. The elevated diapycnal supply of DOC to the upper oxycline, which cannot be explained by microbial processes solely, hints at the presence of an additional DOM removal mechanism, such as microgel formation or adsorption onto particles.

Data availability. The microstructure profiles are available at https://doi.org/10.1594/PANGAEA.868400 (Thomsen, 2016). The $\mathrm{O}_{2}$, temperature, salinity, chl $a$ fluorescence are available at https://doi.org/10.1594/PANGAEA.848017 (Krahmann, 2015) and nutrient concentrations were published at https://doi.org/10.1594/PANGAEA.862055 (Lavik and Krahmann, 2016). The DOC, TDN, DCCHO and DHAA concentrations are available at https://doi.org/10.1594/PANGAEA.900929 (Loginova and Engel, 2019).

Author contributions. ANL collected samples for DOM during the cruise and performed analyses on the data. ST measured microstructure during the M93 cruise. JL performed diapycnal fluxes and supply calculations under the supervision of ST and MD. ANL prepared the manuscript with the great contribution of ST, MD, AE and JL to the data analyses, interpretation of the results and the writing process.

Competing interests. The authors declare that they have no conflict of interest.
Acknowledgements. We thank the chief scientists of the M93 cruise, Gaute Lavik and Torsten Kanzow, for station planning and support during sampling, as well as the crew and scientists onboard. We are also grateful to Gerd Krahmann for processing the CTD data, to Caroline Mages and Ruth Flerus for help with the water sampling, and to Jon Roa and Ruth Flerus for technician support. Special thanks to Frederic Le Moigne for help with the NPP calculation. We thank anonymous referee 1 and Ronald Benner for their valuable comments on improving the manuscript.

Financial support. This research has been supported by the Deutsche Forschungsgemeinschaft (grant no. SFB754 "ClimateBiogeochemical Interactions in the Tropical Ocean" (subproject B9) and CP1403 "Transfer and remineralization of biogenic elements in the tropical oxygen minimum zones").

The article processing charges for this open-access publication were covered by a Research Centre of the Helmholtz Association.

Review statement. This paper was edited by Gerhard Herndl and reviewed by Ronald Benner and one anonymous referee.

\section{References}

Amon, R. M. W., Fitznar, H. P., and Benner, R.: Linkages among the bioreactivity, chemical composition, and diagenetic state of marine dissolved organic matter, Limnol. Oceanogr., 46, 287297, https://doi.org/10.4319/lo.2001.46.2.0287, 2001.

Behrenfeld, M. J. and Falkowski, P. G.: Photosynthetic rates derived from satellite-based chlorophyll concentration, Linmol. Oceanogr., 42, 1-20, https://doi.org/10.4319/lo.1997.42.1.0001, 1997a.

Bender, M. L. and Heggie, D. T.: Fate of organic carbon reaching the deep sea floor: a status report, Geochim. Cosmochim. Ac., 48, 977-986, 1984.

Benner, R.: Chemical composition and reactivity, in: Biogeochemistry of Marine Dissolved Organic Matter, edited by: Hansell, D. A. and Carlson, C. A., 59-90 Academic Press, London, UK, 2002.

Bradley, P. B., Sanderson, M. P., Frischer, M. E., Brofft, J., Booth, M. G., Kerkhof, L. J., and Bronk, D. A.: Inorganic and organic nitrogen uptake by phytoplankton and heterotrophic bacteria in the stratified Mid-Atlantic Bight, Estuar. Coast. Shelf S., 88, 429441, 2010.

Brandt, P., Bange, H. W., Banyte, D., Dengler, M., Didwischus, S.-H., Fischer, T., Greatbatch, R. J., Hahn, J., Kanzow, T., Karstensen, J., Körtzinger, A., Krahmann, G., Schmidtko, S., Stramma, L., Tanhua, T., and Visbeck, M.: On the role of circulation and mixing in the ventilation of oxygen minimum zones with a focus on the eastern tropical North Atlantic, Biogeosciences, 12, 489-512, https://doi.org/10.5194/bg-12-489-2015, 2015.

Chang, B. X., Devol, A. H., and Emerson, S. R.: Denitrification and the nitrogen gas excess in the eastern tropical South $\mathrm{Pa}$ cific oxygen deficient zone, Deep-Sea Res. Pt. I, 57, 1092-1101, https://doi.org/10.1016/j.dsr.2010.05.009, 2010. 
Chin, W.-C., Ollerana, M. V., and Verdugo, P.: Spontaneous assembly of marine dissolved organic matterinto polymers gels, Nature, 391, 568-572, 1998.

Czeschel, R., Stramma, L., Schwarzkopf, F. U., Giese, B. S., Funk, A., and Karstensen, J.: Middeldepth circulation of the easterntropical South Pacific and its link to the oxygen minimum zone, J. Geophys. Res.-Oceans, 116, C1015, https://doi.org/10.1029/2010jc006565, 2011.

Dale, A. W., Sommer, S., Lomnitz, U., Montes, I., Treude, T., Liebetrau, V., Gier, J., Hensen, C., Dengler, M., Stolpovsky, K., Bryant, L. D., and Wallmann, K.: Organic carbon production, mineralisation and preservation on the Peruvian margin, Biogeosciences, 12, 1537-1559, https://doi.org/10.5194/bg-12-1537-2015, 2015.

Dauwe, B. and Middelburg, J. J.: Amino acids and hexoamines as indicators of organic matter degradation state in North Sea sediments, Linmol. Oceanogr., 43, 782-798, 1998.

Davis, J. and Benner, R: Quantitative estimates of labile and semilabile dissolved organic carbon in the western Arctic Ocean: A molecular approach, Limnol. Oceanogr., 52, 2434-2444, 2007.

Davis, J., Kaiser, K., and Benner, R.: Amino acid and amino sugar yields and compositions as indicators of dissolved organic matter diagenesis, Org. Geochem., 40, 343-352, https://doi.org/10.1016/j.orggeochem.2008.12.003, 2009.

Dickson, A. G., Sabine, C. L., and Christian, J. R.: Guide to best practices for ocean $\mathrm{CO}_{2}$ measurements, PICES Special Publication; 3 IOCCP Report; 8, SOP 7, Sydney, Canada, 2007, available at: http://hdl.handle.net/11329/249 (last access: 9 May 2019), 2007.

Dittmar T., Cherrier, J., and Ludwichowski, K. U.: The analysis of amino acids in seawater, in: Practical Guidelines for the analysis of seawater, edited by: Wurl, O., Taylor \& Francis Group, 67-77, CRC Press, Florida, USA, 2009.

Echevin, V., Aumont, O., Ledesma, J., and Flores, G.: The seasonal cycle of surface chlorophyll in the Peruvian upwelling system: A modelling study, Prog. Oceanogr., 79, 167-176, 2008.

Ekau, W., Auel, H., Pörtner, H.-O., and Gilbert, D.: Impacts of hypoxia on the structure and processes in pelagic communities (zooplankton, macro-invertebrates and fish), Biogeosciences, 7, 1669-1699, https://doi.org/10.5194/bg-7-1669-2010, 2010.

Emerson, S., Quay, P., Karl, D., Winn, C., Tupas, L., and Landry, M.: Experimental determination of the organic carbon flux from open-ocean surface waters, Nature, 389, 951-954, https://doi.org/10.1038/40111, 1997.

Engel, A. and Galgani, L.: The organic sea-surface microlayer in the upwelling region off the coast of Peru and potential implications for air-sea exchange processes, Biogeosciences, 13, 989-1007, https://doi.org/10.5194/bg-13-989-2016, 2016.

Engel, A. and Händel, N.: A novel protocol for determining the concentration and composition of sugars in particulat and in high molecular weight dissolved organic matter (HMW-DOM) in seawater, Mar. Chem., 127, 180-191, 2011.

Engel, A., Thoms, S., Riebesell, U., Rochelle-Newall, E., and Zondervan, I.: Polysaccharide aggregation as a potential sink of marine dissolved organic carbon, Nature, 428, 929-932, 2004.

Engel, A., Harlay, J., Piontek, J., and Chou, L.: Contribution of combined carbohydrates to dissolved and particulate organic carbon after the spring bloom in the northern Bay of Biskay (North-Eastern Atlantic Ocean), Cont. Shelf Res., 45, 42-53, https://doi.org/10.1016/j.csr.2012.05.016, 2012.
Fischer, T., Banyte, D., Brandt, P., Dengler, M., Krahmann, G., Tanhua, T., and Visbeck, M.: Diapycnal oxygen supply to the tropical North Atlantic oxygen minimum zone, Biogeosciences, 10, 5079-5093, https://doi.org/10.5194/bg-10-5079-2013, 2013.

Franz, J., Krahmann, G., Lavik, G., Grasse, P., Dittmar, T., and Riebesell, U.: Dynamics and stoichiometry of nutrients and phytoplankton in waters influenced by the oxygen minimum zone in the eastern tropical Pacific, Deep-Sea Res. Pt. I, 62, 20-31, 2012a.

Franz, J. M. S., Hauss, H., Sommer, U., Dittmar, T., and Riebesell, U.: Production, partitioning and stoichiometry of organic matter under variable nutrient supply during mesocosm experiments in the tropical Pacific and Atlantic Ocean, Biogeosciences, 9, 46294643, https://doi.org/10.5194/bg-9-4629-2012, 2012b.

Gagosian, R. B., Nigrelli, G. E., and Volkman, J. K.: Vertical Transport and Transformation of Biogenic Organic Compounds from a Sediment Trap Experiment Off the Coast of Peru, in: Coastal Upwelling Its Sediment Record, edited by: Suess, E. and Thiede J., NATO Conference Series (IV Marine Sciences), Vol. 10B, Springer, Boston, MA, 1983.

Galgani, L. and Engel, A.: Changes in optical characteristics of surface microlayers hint to photochemically and microbially mediated DOM turnover in the upwelling region off the coast of Peru, Biogeosciences, 13, 2453-2473, https://doi.org/10.5194/bg-132453-2016, 2016.

Gilly, W. F., Beman, J. M., Litvin, S. Y., and Robinson, B. H.: Oceanographic and biological effects of shoaling of the oxygen minimum zone, Annu. Rev. Mar. Sci., 5, 393-420, https://doi.org/10.1146/annurev-marine-120710-100849, 2013.

Goldberg, S. J. Carlson, C. A., Bock, B., Nelson, N. B., and Siegel D. A.: Meridional variability in dissolved organic matter stocks and diagenetic state within the euphotic and mesopelagic zone of the North Atlantic subtropical gyre, Mar. Chem., 119, 9-21, 2010.

Graco, M. I., Purca, S., Dewitte, B., Castro, C. G., Morón, O., Ledesma, J., Flores, G., and Gutiérrez, D.: The OMZ and nutrient features as a signature of interannual and low-frequency variability in the Peruvian upwelling system, Biogeosciences, 14, 4601-4617, https://doi.org/10.5194/bg-14-4601-2017, 2017.

Hansell, D. A.: Recalcitrant Dissolved Organic Carbon Fractions, Annu. Rev. Mar. Sci., 5, 421-445, 2013.

Hansen, H. P.: Determination of oxygen, in: Methods of seawater analysis, edited by: Grasshoff, K., Kremling, K., and Ehrhardt, M., 3rd Edn., 75-90, Verlag Chemie, https://doi.org/10.1002/9783527613984.ch4, 2007.

Harvey, H. R., Tuttle, J. H., and Bell, J. T.: Kinetics of phytoplankton decay during stimulated sedimentation: Changes in biochemical composition and microbial activity under oxic and anoxic conditions, Geochim. Cosmochim. Ac., 59, 3367-3377, 1995.

Husson, F., Le, S., and Pagès, J.: Exploratory Multivariate Analysis by Example using R, CRC Press, Boca Raton, 2010.

Ittekot, V., Brockmann, U., Michaels, W., and Degens, E. T.: Dissolved free and combined carbohydrates during a phytoplankton bloom in the northern North Sea, Mar. Ecol.-Prog. Ser., 4, 299305, 1981.

Kaiser, K. and Benner, R.: Biochemical composition and size distribution of organic matter at the Pacific and Atlantic time-series station, Mar. Chem., 113, 63-77, https://doi.org/10.1016/j.marchem.2008.12.004, 2009. 
Kaiser, K. and Benner, R.: Organic matter transformations in the upper mesopelagic zone of the North Pacific: Chemical composition and linkages to microbial community structure, J. Geophys. Res., 117, C01023, https://doi.org/10.1029/2011JC007141, 2012

Kalvelage, T., Lavik, G., Lam, P., Contreras, S., Arteaga, L., Löscher, C. R., Oschlies, A., Paulmier, A., Stramma, L., and Kuypers, M. M. M.: Nitrogen cycling driven by organic matter export in the south pacific oxygen minimum zone, Nat. Geosci., 6, 228-234, 2013.

Kalvelage, T., Lavik, G., Jensen, M. M., Revsbech, N. P., Löscher, C., Schunck, H., Desai, D. K., Hauss, H., Kiko, R., Holtappels, M., LaRoche, J., Schmitz, R. A., Graco, M. I., and Kuypers, M. M. M.: Aerobic microbial respiration in oceanic oxygen minimum zones, PLoS ONE, 10, e0133526, https://doi.org/10.1371/journal.pone.0133526, 2015.

Karstensen, J., Stramma, L., and Visbeck, M.: Oxygen minimum zones in the eastern tropical Atlantic and Pacific oceans, Prog. Oceanogr., 77, 331-350, https://doi.org/10.1016/j.pocean.2007.05.009, 2008.

Kock, A., Schafstall, J., Dengler, M., Brandt, P., and Bange, H. W.: Sea-to-air and diapycnal nitrous oxide fluxes in the eastern tropical North Atlantic Ocean, Biogeosciences, 9, 957-964, https://doi.org/10.5194/bg-9-957-2012, 2012.

Krahmann, G.: Physical oceanography during METEOR cruise M93, PANGAEA, https://doi.org/10.1594/PANGAEA.848017, 2015.

Lavik, G. and Krahmann, G.: Hydrochemistry of water samples during METEOR cruise M93, PANGAEA, https://doi.org/10.1594/PANGAEA.862055, 2016.

Lavin, P., González, B., Santibáñez, J. F., Scanlan, D. J., and Ulloa, O.: Novel lineages of Prochlorococcus thrive within the oxygen minimum zone of the eastern tropical South Pacific, Env. Microbiol. Rep., 2, 728-738, 2010.

Lee, C., Wakeham, S. G., and Hedges, J. I.: Composition and flux of particulate amino acid and chloropigments in equatorial Pacific seawater and sediments, Deep-Sea Res. Pt. I, 47, 1535-1568, 2000

Lefévre, D., Denis, M., Lambert, C. E., and Miquel, J.-C.: Is DOC the main source of organic matter remineralization in the ocean water column?, J. Marine Syst., 7, 281-291, doi:10.1016/09247963(95)00003-8, 1996.

Letscher, R. T., Hansell, D. A., Carlson, C. A., Lumpkin, R., and Knapp, A. N.: Dissolved organic nitrogen dynamics in global surface ocean: distribution and fate, Global Biogeochem. Cy., 27, 141-153, 2013.

Lindroth, P. and Mopper, K.: High performance liquid chromatographic determination of subpicomole amounts of amino acids by precolumn fluorescence derivatization with $o$ phthaldialdehyde, Anal. Chem., 51, 1667-1674, 1979.

Loginova, A. and Engel, A.: Dissolved oganic matter measurements off Peru, PANGAEA, https://doi.org/10.1594/PANGAEA.900929, 2019.

Loginova, A. N., Borchard, C., Meyer, J., Hauss, H., Kiko, R., and Engel, A.: Effects of nitrate and phosphate supply on chromophoric and fluorescent dissolved organic matter in the Eastern Tropical North Atlantic: a mesocosm study, Biogeosciences, 12, 6897-6914, https://doi.org/10.5194/bg-12-6897-2015, 2015.
Loginova, A. N., Thomsen, S., and Engel, A.: Chromophoric and fluorescent dissolved organic matter in and above the oxygen minimum zone off Peru, J. Geophys. Res.-Oceans, 121, 79737990, https://doi.org/10.1002/2016JC011906, 2016.

Löscher, C. R., Bange, H. W., Schmitz, R. A., Callbeck, C. M., Engel, A., Hauss, H., Kanzow, T., Kiko, R., Lavik, G., Loginova, A., Melzner, F., Meyer, J., Neulinger, S. C., Pahlow, M., Riebesell, U., Schunck, H., Thomsen, S., and Wagner, H.: Water column biogeochemistry of oxygen minimum zones in the eastern tropical North Atlantic and eastern tropical South Pacific oceans, Biogeosciences, 13, 3585-3606, https://doi.org/10.5194/bg-133585-2016, 2016.

Mahadevan, A.: Eddy effects on biogeochemistry, Nature, 506, 168-169, 2014.

McDougall, T. J. and Barker, P. M.: Getting started with TEOS and the Gibbs Seawater (GSW) Oceanographic Toolbox, 28 pp., SCOR/IAPSO WG127, ISBN 978-0-646-55621-5, 2011.

Meyer, J., Löcher, C. R., Lavik, G., and Riebesell, U.: Mechanisms of $\mathrm{P}^{*}$ reduction in the eastern tropical South Pacific, Front. Mar. Sci., 4, 1-12, https://doi.org/10.3389/fmars.2017.00001, 2017.

Nguyen R. T. and Harvey, H. R.: Protein and amino acid cycling during phytoplankton decomposition in oxic and anoxic waters, Org. Geochem., 27, 115-128, 1997.

Ogawa, H. and Tanoue, E.: Dissolved Organic Matter in Oceanic Waters, J. Oceanogr., 59, 129-147, 2003.

Osborn, T. R.: Estimates of the local rate of vertical diffusion from dissipation measurements, J. Phys. Oceanogr., 10, 83-89, 1980.

Pantoja, S. and Lee, C.: Amino acid remineralization and organic matter lability in Chilean coastal sediments, Org. Geochem., 34, 1047-1056, 2003.

Pantoja, S., Sepúlveda, J., and González, H. E.: Decomposition of sinking proteinaceous material during fall in the oxygen minimum zone off northern Chile, Deep-Sea Res. Pt. I, 51, 55-70, https://doi.org/10.1016/j.dsr.2003.09.005, 2004.

Pantoja, S., Rossel, P., Castro, R., Cuevas, L. A., Daneri, G., and Córdova, C.: Microbial degradation rates of small peptides and amino acids in the oxygen minimum zone of Chilean coastal waters, Deep-Sea Res. Pt. II, 56, 1055-1062, 2009.

Paulmier, A. and Ruiz-pino, D.: Oxygen minimum zones (OMZs) in the modern ocean, Prog. Oceanogr., 80, 3-4, https://doi.org/10.1016/j.pocean.2008.08.001, 2009.

Pennington, J. T., Mahoney, K. L., Kuwahara, V. S., Kolber, D. D., Calienes, R., and Chavez, F. P.: Primary production in the eastern tropical pacific: A review, Prog. Oceanogr., 69, 285-317, https://doi.org/10.1016/j.pocean.2006.03.012, 2006.

R Core Team: R: A language and environment for statistical computing. R Foundation for Statistical Computing, Vienna, Austria, available at: https://www.R-project.org/ (last access: 9 May 2019), 2013.

Revsbech, N. P., Larsen, L. H., Gundersen, J., Dalsgaard, T., Ulloa, O., and Thamdrup, B.: Determination of ultralow oxygen concentrations in oxygen minimum zones by the stox sensor, Limnol. Oceanogr.-Meth., 7, 371-381, https://doi.org/10.4319/lom.2009.7.371, 2009.

Romankevich, E. A. and Ljutsarev, S. V.: Dissolved organic carbon in the ocean, Mar. Chem., 30, 161-178, 1990.

Schafstall, J., Dengler, M., Brandt, P., and Bange, H. W.: Tidal induced mixing and diapycnal nutrient fluxes in the Mau- 
ritanian upwelling region, J. Geophys. Res., 115, C10014, https://doi.org/10.1029/2009JC005940, 2010.

Sempéré, R., Tedetti, M., Panagiotopoulos, C., Charrière, B., and Van Wambeke, F.: Distribution and bacterial availability of dissolved neutral sugars in the South East Pacific, Biogeosciences, 5, 1165-1173, https://doi.org/10.5194/bg-5-1165-2008, 2008.

Skoog, S. and Benner, R.: Aldoses in various size fractions of marine organic matter: Implications for carbon cycling, Limnol. Oceanogr., 42, 1803-1813, 1997.

Smith, D. C., Simon, M., Alldredge, A. L., and Azam, F.: Intense hydrolytic enzyme activity on marine aggregates and implications for rapid particle dissolution, Nature, 359, 139-142, https://doi.org/10.1038/359139a0, 1992.

Steinfeldt, R., Sültenfuß, J., Dengler, M., Fischer, T., and Rhein, M.: Coastal upwelling off Peru and Mauritania inferred from helium isotope disequilibrium, Biogeosciences, 12, 7519-7533, https://doi.org/10.5194/bg-12-7519-2015, 2015.

Strady, E., Pohl, C., Yakushev, E. V., Krüger, S., and Hennings, U.: PUMP-CTD-System for trace metal sampling with a high vertical resolution. A test in the Gotland Basin, Baltic Sea, Chemosphere, 70, 1309-1319, 2008.

Thomsen, S.: Microstructure Measurements during METEOR cruise M93. GEOMAR - Helmholtz Centre for Ocean Research Kiel, PANGAEA, https://doi.org/10.1594/PANGAEA.868400, 2016.

Thomsen, S., Kanzow, T., Krahmann, G., Greatbatch, R. J., Dengler, M., and Lavik, G.: The formation of a subsurface anticyclonic eddy in the Peru-Chile Undercurrent and its impact on the near-coastal salinity, oxygen and nutrient distributions, J. Geophys. Res.-Oceans, 121, 476-501, https://doi.org/10.1002/2015JC010878, 2016a.
Thomsen, S., Kanzow, T., Colas, F., Echevin, V., Krahmann, G., and Engel, A.: Do submesoscale frontal processes ventilate the oxygen minimum zone off Peru?, Geophys. Res. Lett., 43, 81338142, https://doi.org/10.1002/2016GL070548, 2016 b.

Tiano, L., Garcia-Robledo, E., Dalsgaard, T., Devol, A. H., Ward, B. B., Ulloa, O., Canfield, D. E., and Revsbech, N. P.: Oxygen distribution and aerobic respiration in the north and south eastern tropical Pacific oxygen minimum zones, Deep-Sea Res. Pt. I, 94, 173-183, 2014.

Verdugo, P., Alldredge, A. L., Azam, F., Kirchman, D. L., Passow, U., and Santschi, P. H.: The oceanic gel phase: A bridge in the DOM-POM continuum, Mar. Chem., 92, 67-85, 2004.

Winkler, L. W.: Die Bestimmung des Wassers gelösten Sauerstoffes, Ber. Dtsch. Chem. Ges., 21, 2843-2854, https://doi.org/10.1002/cber.188802102122, 1888.

Ulloa, O., Canfield, D. E., DeLong, E. F., Letelier, R. M., and Stewart, F. J.: Microbial oceanography of anoxic oxygen minimum zones, P. Natl. Acad. Sci. USA, 109, 15996-16003, https://doi.org/10.1073/pnas.1205009109, 2012.

Zepp, R. G., Callaghan, T. V., and Erickson, D. J.: Effects of enhanced solar ultraviolet radiation on biogeochemical cycles, UNEP, Environmental effects of ozone depletion: 1998 Assessment, United Nations Environment Programme, 205 pp., Secretariat for The Vienna Convention for the Protection of the Ozone Layer and The Montreal Protocol on Substances that Deplete the Ozone Layer United Nations Environment Programme (UNEP) Nairobi Kenya, ISBN 92-807-1724-3, 1998. 